\title{
Lip and Oral Cavity Cancer pT2 TNM Finding v8
}

National Cancer Institute

\section{Source}

National Cancer Institute. Lip and Oral Cavity Cancer PT 2 TNM Finding v8. NCI

Thesaurus. Code C132696.

Lip and oral cavity cancer with tumor size $2 \mathrm{~cm}$ or less in greatest dimension, DOI greater than $5 \mathrm{~mm}$ and equal or less than $10 \mathrm{~mm}$ or tumor greater than $2 \mathrm{~cm}$ but $4 \mathrm{~cm}$ or less in greatest dimension and $10 \mathrm{~mm}$ or less DOI. (from AJCC 8th Ed.) 